Paweł Bąk, Die Metapher in der Übersetzung. Studien zum Transfer der Aphorismen von Stanisław Jerzy Lec und der Gedichte von Wisława Szymborska, Peter Lang Europäischer Verlag der Wissenschaften, Frankfurt am Main u. a. 2007 = Danziger Beiträge zur Germanistik, Bd. 20 wyd. Andrzej Kątny, 332 strony.

Niniejsza recenzja składa się z dwóch części: z możliwie krótkiego omówienia treści książki oraz z trochę szerszej próby oceny. Obie części wydają się istotne dla potencjalnego czytelnika, bo chciałby on pozyskać możliwie dużo relewantnych informacji, uzasadniających zakup recenzowanej pozycji lub rezygnację $\mathrm{z}$ niego, tym bardziej że książki publikowane przez wydawnictwo Peter Lang do najtańszych nie należą. Właśnie cena książki (w przeliczeniu przeszło 200 złotych) budzi pewne wątpliwości co do zasadności publikacji niniejszej recenzji w piśmie adresowanym głównie do polskiego środowiska przekładoznawców i tłumaczy. Wydaje się bowiem, że omawiana książka nie znajdzie zbyt wielu czytelników na rynku polskim, a to przypuszczenie przemawiałoby raczej za napisaniem recenzji w języku niemieckim.

\title{
Zarys treści
}

Oprócz wstępu i uwag końcowych oraz wykazu literatury książka składa się $\mathrm{z}$ dwóch głównych części, które nie zostały formalnie wyodrębnione. Pierwszą część stanowią rozważania teoretyczne dotyczące m.in. definicji metafory, jej funkcji w tekstach literackich, sposobu jej opisu w teoriach przekładu oraz oceny w analizie czy krytyce przekładu. Drugą część stanowi właściwa analiza transferu metafor $\mathrm{w}$ tłumaczeniach wybranych aforyzmów Stanisława Jerzego Leca i wierszy Wisławy Szymborskiej, zakończona wyciągnięciem stosownych wniosków. Jeżeli przyjmiemy zaproponowane rozróżnienie, do części teoretycznej należą początkowe cztery, a do analitycznej, włączywszy w nią wyciągnięte wnioski, następne trzy rozdziały pracy.

Przedmiotem rozważań rozdziału pierwszego jest problematyka definicji pojęcia „metafora”, ujęta historycznie, począwszy od definicji Arystotelesa. Trochę szczegółowiej autor omówił rozumienie metafory przez Ha- 
ralda Weinricha, Maxa Blacka, przedstawicieli koncepcji kognitywistycznych (G. Lakoff, M. Johnson, R. W. Langacker, M. Turner) oraz kilku innych badaczy, by przejść w dalszej części do klasyfikacji metafor (1.6) i wyjaśnienia ich istoty (1.7).

W rozdziale drugim P. Bąk zajął się funkcją metafory w tekstach literackich, odwołując się w końcowej jego części ponownie do koncepcji Weinricha, w trzecim zaś włączył do rozważań teorie przekładu, koncentrując uwagę na problematyce przekładu metafory i prezentując związane $\mathrm{z}$ tym zagadnieniem koncepcje. Szczegółowiej przedstawiono ujęcie N. Hofmanna, R. van den Broecka, W. Walthera, P. Newmarka, M. Snell-Hornby, U. Kjära, P. Kosty, E.-N. Kurtha i E. Tabakowskiej.

W rozdziale czwartym autor omówił zastosowaną w badaniu metodę i scharakteryzował obszary, których analiza dotyczy. Ten rozdział stanowi zatem element łączący część teoretyczną z częścią analityczną rozprawy.

W rozdziale piątym dokonano dość szczegółowej analizy tłumaczeń 42 aforyzmów Stanisława Jerzego Leca na język niemiecki, przy czym główny akcent badania położono nie na całości tłumaczenia, lecz zgodnie z tytułem pracy na wyrażenia, uznane przez P. Bąka za metafory. Autorem wszystkich badanych tłumaczeń jest Karl Dedecius, co autor wyraźnie podkreśla. Analiza ma w większości charakter opisowy i zawiera opis metody zastosowanej w przekładzie metafor oraz niekiedy ocenę wysiłku tłumacza. W podobny sposób podchodzi autor do będącej przedmiotem rozdziału szóstego analizy fragmentów wierszy laureatki nagrody Nobla Wisławy Szymborskiej. W tym przypadku badaniu poddano 60 krótkich fragmentów wierszy zawierających metafory. Struktura analizy różni się nieco od analizy aforyzmów, gdyż zastosowano dodatkowe charakterystyczne dla literatury pięknej kryteria.

$\mathrm{W}$ rozdziale siódmym autor przedstawił wyniki przeprowadzonych badań, odnosząc się na pięciu stronach do piątego, na dziesięciu zaś do szóstego rozdziału. Pracę zamykają uwagi końcowe i wykaz wykorzystanej literatury.

\section{Kilka uwag, próba oceny}

Uważny czytelnik rozprawy P. Bąka łatwo dostrzeże, że nie jest ona wolna od niekonsekwencji i drobnych potknięć, które pokrótce postaram się wypunktować. Do niekonsekwencji w pracy zaliczyć można przyporządkowanie niektórych pozycji w spisie literatury do jednej z wyodrębnionych grup. Autor wyróżnił m.in. grupę encyklopedii, leksykonów, słowników i innych tego typu publikacji, dla których w języku niemieckim istnieje termin Nachschla- 
gewerke, wyrażający przede wszystkim ich funkcję, gdyż czasownik nachschlagen oznacza 'sprawdzić, wyszukać.' Chodzi zatem o te pozycje, po które sięgamy, by coś sprawdzić lub szybko odnaleźć, których się raczej nie czyta w całości. Oczywiście nie jest łatwo wyznaczyć granicę dla tej kategorii i dlatego można się spierać, czy określoną książkę zaliczyć do niej, czy nie. Jednakże nie samo przypisanie jest przedmiotem krytyki, lecz brak konsekwencji, gdyż autor z jednej strony uznaje Mała encyklopedię przekładoznawstwa pióra Urszuli Dąbskiej-Prokop za Nachschlagewerk, a odmawia tego statusu wydanemu przez Jurija Lukszyna Tezaurusowi terminologii translatorycznej. To samo dotyczy Niemiecko-polskiej gramatyki kontrastywnej ${ }^{1}$ wydanej przez Ulricha Engela i Gramatyki komunikacyjnej, wydanej przez Aleksego Awdiejewa. Pierwszą pozycję zakwalifikowano do wspomnianej kategorii, drugiej nie. Omawiając niedociągnięcia w spisie literatury, nie sposób nie zauważyć, że część podanych w nim pozycji nie jest w książce cytowana.

Następną niekonsekwencję znajdziemy w kwestii tłumaczenia cytatów. $\mathrm{Z}$ uwagi na przedmiot pracy rzeczona niekonsekwencja dziwi. Cytując fragment z książki E. Tabakowskiej (s. 107), autor dokonał stosownego tłumaczenia na język niemiecki, podczas gdy kilka stron wcześniej decyduje się nie tłumaczyć fragmentu z książki M. Snell-Hornby (s. 99, 100). Oczywiście można przyjąć, że autor założył powszechną znajomość języka angielskiego wśród potencjalnych czytelników. Jeśli tak było, to mógł z jeszcze większą pewnością przyjąć znajomość języka polskiego wśród potencjalnych czytelników, gdyż tematyka książki związana jest ściśle z tłumaczeniem z języka polskiego na niemiecki, więc ciężko wyobrazić sobie, że zainteresowany problematyką czytelnik nie będzie znał języka polskiego. Trudno zatem znaleźć jakieś sensowne uzasadnienie wspomnianej niekonsekwencji.

Do tej kategorii (niekonsekwencja) należy również szyk wyrażeń określających metodę czy technikę tłumaczenia. Na stronie $153 \mathrm{w}$ jednym przypadku spotykamy określenie „bezpośrednie, restytucyjne tłumaczenie”, w drugim zaś „restytucyjne, bezpośrednie tłumaczenie”. To samo powtarza się na stronach 156, 157. Właściwie tego typu niedociągnięcie czy też inne drobiazgi, jak niepotrzebne kropki po tytule podrozdziału (s. 139) lub po ostatniej cyfrze w jego numeracji (s. 135), powinny być wyeliminowane na poziomie redakcji. Jednakże Peter Lang Verlag funkcjonuje bardziej jak drukarnia niż wydawnictwo, nie zajmując się tego typu pracami redakcyjnymi i powierzając je autorom, stąd błędy techniczne w wydawanych publikacjach nie mogą należeć i nie należą do rzadkości.

\footnotetext{
1 W oryginale tytuł brzmi Deutsch-polnische kontrastive Grammatik.
} 
Do słabych stron publikacji należy również brak jasnej, przemyślanej korelacji między częścią teoretyczną i analityczną. Opisywanie różnego rozumienia pojęcia "metafora” dowodzi wprawdzie, że autor zapoznał się ze stosowną literaturą, nie wnosi jednakże wiele nowego, bo większość tych zagadnień została już wcześniej wielokrotnie opisana. Poza tym sam sposób przedstawienia zagadnienia jest dość rozmyty, gdyż czytelnik nie wie, ku jakiej koncepcji skłania się autor i dlaczego. Czytając między wierszami, można się domyśleć, że częściowo bliskie mu jest ujęcie kognitywistów i koncepcja Weinricha. Koncept kognitywistów nie jest jednakże w całości akceptowany, o czym świadczy następująca uwaga na stronie 56 :

Pogląd reprezentowany w kognitywnych badaniach metafory mówiący, że metafory są wszędzie obecne, nie traktuję jako wszechobecność metafor każdego rodzaju. Pojawienie się metafory w określonym kontekście i sytuacji może służyć grze (zabawie), którą często da się stwierdzić, która jednakże nie dotyczy wyłącznie metafor zleksykalizowanych i skonwencjonalizowanych. $Z$ tego typu świadomym traktowaniem metafor będziemy mieli do czynienia w niniejszej pracy.

Cytowany fragment obrazuje, że autor miast określić jasno swoje stanowisko lawiruje między różnymi koncepcjami (por. s. 54-55). Oczywiście można przypuszczać, że chodzi mu o jakieś połączenie wielu koncepcji w jeden holistyczny model, niemniej nawet wówczas należało jasno powiedzieć, jakie elementy i z jakiej koncepcji model ów konstytuują. $Z$ drugiej strony mogło być i tak, że autor, wychodząc od badań empirycznych, dostrzegł, że większość opisywanych modeli w jakiś sposób da się zaaplikować do badanej rzeczywistości, ale żaden nie pasuje do końca. Dostrzegając twórcze podejście do metafor Leca i Szymborskiej, a nawet świadome eksperymentowanie na nich, Bąk wychodzi poza granice wytyczone poszczególnymi koncepcjami metafor, wnosząc trochę przez przypadek, bo nie to jest głównym tematem pracy, swój wkład do badań nad metaforą. Jednakże ów brak jednoznacznego określenia utrudnia potencjalnemu czytelnikowi ocenę części analitycznej pracy, bo nie da się podjąć polemiki, czy zakwalifikowane jako metafora zjawisko faktycznie nią jest.

Ważnym elementem recenzowanej pracy jest rozdział trzeci, wyraźnie łączący zjawisko metafory z właściwym tematem pracy, tzn. z jej tłumaczeniem. Autor dobrze przestudiował koncepcje teoretyków i praktyków przekładu i zestawił główne poglądy na temat tłumaczeń metafor. Jednak błędem wydaje się struktura tego rozdziału, gdyż lepiej byłoby wyjść od samego problemu tłumaczenia metafory i określić jego części składowe, pokazując, jakich rozwiązań dostarczają teoretycy tłumaczeń, oraz akcentując, jakie rozwiązania są wspólne 
dla nich, a w jakich elementach się różnią. Streszczanie poglądów poszczególnych badaczy i przyjęcie nazwiska badacza jako podstawy podziału rozdziału, powoduje konieczność powtarzania tych samych bądź bardzo podobnych treści. Autor prawdopodobnie dostrzegł ten problem, gdyż w części rozdziału jednak definiuje zjawiska i problemy związane $\mathrm{z}$ tłumaczeniem metafory i one stanowią kryterium podziału $(3.2,3.3,3.4,3.5)$. Jednak i w tym przypadku widać brak konsekwencji, gdyż dalszy podział punktu 3.5 nie stanowi drążenia podjętego wątku, lecz odnosi się znów do koncepcji poszczególnych teoretyków; punkt 3.5.1 - do Ernsta-Norberta Kurtha, punkt 3.5.2 - do Elżbiety Tabakowskiej, a tytuły tych punktów składają się z wymienienia podanych nazwisk.

Przechodząc do omówienia części analitycznej, należy zauważyć, że autor dość dokładnie analizuje poszczególne przykłady. W niektórych przypadkach wyraża on również swoją ocenę, nie wahając się w przypadku sądów pozytywnych napisać o nich (por. przykład 13 na s. 149). W przypadku określonych uwag, wymuszonych systemowo zmian itd. P. Bąk raczej stara się opisywać zjawiska, nie formułując przy tym negatywnych ocen. W niektórych przypadkach można sądzić, że jest to swoisty ukłon w stronę Karla Dedeciusa, znakomitego tłumacza, postaci wielce zasłużonej dla kultury polskiej i jej popularyzacji zagranicą. Ponieważ opisowa analiza poszczególnych aforyzmów i fragmentów wierszy świadczą o głębokiej refleksji autora nad badanymi metaforami, należy uznać część empiryczną pracy za poprawną, skłaniającą do dalszych przemyśleń. Brakuje wprawdzie jasnych kryteriów zastosowanych przy ocenie badanego zjawiska, a w samym opisie widać terminologię i metodologię różnych szkół, (kognitywizm - np. obrazowanie, semantyka strukturalna - np. pojęcie semu, literaturoznawstwo), jednakże analizie nie można odmówić sumienności i dokładności. Wymienione cechy powodują, że tę część książki dobrze się czyta.

Konkludując, należy stwierdzić, że rozprawa P. Bąka wnosi poprzez analizowane przykłady nowe impulsy do problematyki przekładu metafor. Można by powiedzieć, że o przekładzie metafor mówi na przykładzie ich tłumaczenia, parafrazując jedną z książek E. Tabakowskiej. Strona metodologiczna i koncepcyjna pracy nie jest idealna, a autorowi łatwiej jest wniknąć w głąb badanego zjawiska, dostrzec i opisać różnorodność występującej w nim problematyki, niż klasyfikować, proponować jakąś typologię czy też tworzyć określone kryteria. Ponieważ sam przeczytałem książkę z przyjemnością, mógłbym ją w tym miejscu polecić. Jej wspomniana na początku recenzji cena może stanowić jednakże trudną do pokonania przeszkodę w znajdowaniu potencjalnych nabywców w Polsce.

Lech Zieliński 